\title{
Instruments for the Evaluation of Alcohol Use in Indigenous Communities - A Systematic Review
}

\author{
Ronaldo Santhiago Bonfim de Souza*, \\ Orcid.org/0000-0001-8543-6935 \\ Júlia Costa de Oliveira ${ }^{1}$ \\ Orcid.org/0000-0003-3899-1092 \\ Vânia Eloisa de Araújo \\ Orcid.org/0000-0002-0345-8522 \\ Maycoln Leôni Martins Teodoro ${ }^{1}$ \\ Orcid.org/0000-0002-3021-8567
}

${ }^{1}$ Universidade Federal de Minas Gerais, Belo Horizonte, MG, Brasil ${ }^{2}$ Pontificia Universidade Católica de Minas Gerais, Belo Horizonte, MG, Brasil

\begin{abstract}
The measurement of alcohol consumption in indigenous populations has been important in order to understand their reasons and thoughts on alcohol use as well as the resulting losses. This study aimed to verify which data collection instruments are nationally and internationally used in the evaluation of alcohol use in indigenous populations, and it was conducted through a systematic review of studies that evaluated alcoholism in the indigenous populations. We searched the databases Medline (Pubmed), Cochrane library, PsycINFO, Lilacs, including gray literature and manual search. A total of 716 selected publications were identified, and after a stepwise evaluation, the final analysis included 30 studies that met the inclusion criteria. Twenty different instruments were used in the studies to evaluate alcohol use in indigenous people, such as questionnaires created from the specificities of the groups and instruments common used in non-indigenous groups, World Health Organization recommends some of them. By allowing greater knowledge about the instruments validated to understand the consumption of alcoholic beverage in these populations, this study contributes to the research about the processes of indigenous alcoholization, allowing a progress in the development of interventions. It also provides an important discussion in the area of psychological assessment and the use of instruments in different cultural contexts.
\end{abstract}

Keywords: Alcoholism, Indigenous population, detection of substance abuse, systematic review.

* Mailing address: Universidade Federal de Minas Gerais, Faculdade de Filosofia e Ciências Humanas, Departamento de Psicologia, Av. Antônio Carlos, 6627, Pampulha, Belo Horizonte, MG, Brasil 31270-901. E-mail: santhiagosouza@yahoo.com.br

Support: Coordenação de Aperfeiçoamento de Pessoal de Nível Superior (CAPES). 


\section{Instrumentos para a Avaliação do Uso de Álcool em Comunidades Indígenas - Revisão Sistemática}

\section{Resumo}

A mensuração do consumo de álcool nas populações indígenas tem sido importante para entender suas razões e pensamentos sobre o uso de álcool, bem como as perdas resultantes. Este estudo teve como objetivo verificar instrumentos de coleta de dados utilizados na avaliação do consumo de álcool em populações indígenas nacional e internacionalmente. Para isso, foi realizada uma revisão sistemática de estudos que avaliaram o uso de álcool em populações indígenas, nas bases de dados Medline (Pubmed), biblioteca Cochrane, PsycINFO, Lilacs, incluindo literatura cinza e busca manual. Foram identificadas 716 publicações selecionadas e, após uma avaliação escalonada, a análise final incluiu 30 estudos que atenderam aos critérios de inclusão. Vinte instrumentos diferentes foram utilizados nos estudos para avaliar o consumo de álcool em povos indígenas, como questionários criados a partir das especificidades desses grupos e instrumentos comumente utilizados em populações não indígenas, sendo alguns preconizados pela Organização Mundial de Saúde. Ao permitir um maior conhecimento sobre os instrumentos validados para entender o consumo de bebidas alcoólicas nessas populações, este estudo contribui para a pesquisa sobre os processos de alcoolização indígena, permitindo progresso no desenvolvimento de intervenções. Fornece, ademais, uma importante discussão na área de avaliação psicológica e uso de instrumentos em diferentes contextos culturais.

Palavras-chave: Alcoolismo, população indígena, detecção de abuso de substância, revisão sistemática.

\section{Instrumentos para la Evaluación del Uso del Alcohol en las Comunidades Indígenas - Revisión Sistemática}

\section{Resumen}

La medición del consumo de alcohol en las poblaciones indígenas ha sido importante para comprender sus razones y pensamientos sobre el consumo de alcohol, así como las pérdidas resultantes. Este estudio tuvo objetivo verificar qué instrumentos de recopilación de datos se utilizan a nível nacional e internacional en la evaluación del consumo de alcohol en las poblaciones indígenas, y se realizó a través de una revisión sistemática de estudios que evaluaron el alcoholismo en las poblaciones indígenas. Se realizaron búsquedas en las bases de datos Medline (Pubmed), Cochrane, PsycINFO, Lilacs, incluyendo literatura gris y búsqueda manual. Se identificaron un total de 716 publicaciones seleccionadas, y después de una evaluación escalonada, el análisis final incluyó 30 estudios que cumplieron con los criterios de inclusión. Se utilizaron 20 instrumentos diferentes en los estudios para evaluar el consumo de alcohol en los pueblos indígenas. Al permitir un mayor conocimiento sobre los instrumentos validados para entender el consumo de bebidas alcohólicas en estas poblaciones, el presente estudio contribuye a la investigación sobre los procesos de alcoholismo indígena, permitiendo un avance en el desarrollo de intervenciones. Además, proporciona una discusión importante en el área de la evaluación psicológica y el uso de instrumentos en diferentes contextos culturales.

Palabras clave: Alcoholismo, población indígena, detección de abuso de sustâncias, revisión sistemática.

According to National Health Foundation (FUNASA, 2002), alcoholism is among the most common health problem in Brazilian indigenous groups, with emphasis on the Northeast, CenterWest, Southeast, and South regions. The aggravation of the situation increases according to the 
proximity of communities to non-indigenous peoples. Interethnic contact, according to Souza and Garnelo (2006), began more than three centuries ago and allowed the introduction of the distilled beverage in the village making changes in the organization of these societies with broader changes in traditional culture. According to Langdon (2013), the current consumption of distilled alcoholic drinks, unlike the traditional custom, can causes negative consequences for indigenous communities, such as general and family violence, malnutrition, children's health impairment, and also can prejudices external relations of the group, with problems of judicial order. In addition, it creates a negative image of the "alcoholic indian", which can be used, erroneously, as justification for their social exclusion.

It is fundamental to recognize the variability of drinking modes in different sociocultural and historical contexts, and to understand that the identification of abnormal patterns of alcohol consumption must be understood by what would be considered a suitable mode of drinking in a given social situation (Edwards, Marshall, \& Cook, 2005). Thus, it is also recognized the sociocultural diversity surrounding the use of alcohol, whose acceptance or disapproval varies according to the history and organization of each society (Souza \& Garnelo, 2006).

The way to approach the construct has a direct impact on the evaluation, since a clear definition is needed, which provides the limitations not only in terms of borders that cannot be overcome, but even more in terms of the boundaries that must be reached in the evaluation of the phenomenon (Pasquali, 2010). Thus, the adopted view on alcohol consumption should be defined in view of the population studied and the context in which it is inserted, guiding the procedures and the means to evaluate the phenomenon.

Since 1996, the World Health Organization (WHO) has emphasized the importance of cultural adaptation of instruments to measure alcohol and drug use in order to establish a "common language" in this theme of global concern (WHO, 2004). The WHO also proposes that a single methodology be adopted to adapt these instruments to better operationalize the process and ensure the quality of the adapted instruments. Souza and Garnelo (2006) argue that, in the application and creation of instruments to evaluate the phenomenon, it is important to consider the premise that guided its construction and the specificities of the cultural reality in which it will be applied.

Culturally adapted instruments have strategic importance in the implantation of future interventions, since it allows the identification of areas where there is a greater problem with the use of alcohol, as well as the most vulnerable groups. This allows for a more rational distribution of the resources to be allocated to this activity, as well as the choice of means of prevention that are more adequate for the different affected groups (Oliveira, 2001). According to this same author, in the Indian universe, perceptions, words, and meaning of things differs from nonindigenous society and it is necessary to adapt instruments to the context investigated.

The lack of knowledge and the lack of instruments adapted to assess the consumption of alcoholic beverages among indigenous people cause limitations for the development of more appropriate actions, and allow the formulation of preconceptions, quite common when speaking about indigenous communities and abusive consumption of alcohol (Langdon, 2001). Thus, the importance of research and the presentation of instruments that consider the social and cultural context of individuals, as well as the use and damages caused by alcohol, are considered. In view of the above issues, a systematic review was conducted with the purpose of summarizing the evidence to verify which data collection instruments are used in the evaluation of alcohol use in indigenous populations.

\section{Method}

A systematic review of studies was conducted that addressed measures to assess alcohol consumption among indigenous peoples. The steps taken in this systematic review are based on the Cochrane method (Clarke \& Oxman, 2000) which is recognized as a gold standard in the 
health area. Also, the article was prepared using the Preferred Reporting Items for Systematic Reviews and Meta-Analysis (PRISMA), which is a guideline to help authors to measure the clarity and transparency of reporting of systematic review and meta-analysis data, consisting of a checklist of 27 items and a four-phase article selection flow diagram (Liberati et al., 2009).

\section{Databases and Search Strategy}

An electronic search of relevant articles published through February of 2016 was conducted systematized in the Medline (PubMed),

Table 1

\section{Search Strategies for Electronic Databases}

Electronic

Databases

Search Strategies

Studies

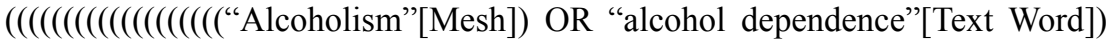
OR "dependence, alcohol"[Text Word]) OR "alcoholic intoxications"[Text Word]) OR "chronic alcoholic intoxication"[Text Word]) OR "alcohol addiction"[Text Word]) OR "addiction, alcohol"[Text Word]) OR "alcohol abuse/alcohol dependence syndrome"[Text Word]) OR "abuse, alcohol"[Text Word]) OR "abuse, alcoholism"[Text Word]) OR "drinking, alcoholics"[Text Word]) OR "alcohol consumption"[Text Word]) OR "alcohol consumption/ abuse"[Text Word]) OR "consumption, alcohol"[Text Word]) OR "drinking/abuse"[Text Word]) OR “drinking/alcohol"[Text Word])) AND

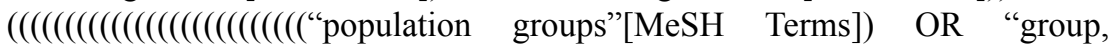
population" [Text Word]) OR "population group"[Text Word]) OR "tribes" [Text Word]) OR “tribes/ethnic"[Text Word]) OR "natives"[Text Word]) OR "native born"[Text Word]) OR "indigenous population”[Text Word]) OR “indigenous Medline populations"[Text Word]) OR Services, Indigenous Health[Text Word])) OR (Pubmed) "american indians"[Text Word]) OR "american indians/alaska"[Text Word]) OR "american indians/alaska natives"[Text Word]) OR "american indians/alaskan natives"[Text Word]) OR “american indians 45"[Text Word]) OR “american indians alaska"[Text Word]) OR "american indians alaska natives"[Text Word]) OR "american indigenous populations"[Text Word]) OR "american indigenous adolescents"[Text Word]) OR "american indigenous peoples"[Text Word]) OR "native american"[Text Word]) OR "indigenous adolescents"[Text Word]) OR "aboriginum"[Text Word]) OR "aboriginal"[Text Word]))) AND (()(()((()“substance abuse detection"[MeSH Terms]) OR "questionnaire”[Text Word]) OR "substance abuse screening instruments"[Text Word]) OR "substance abuse screening"[Text Word]) OR "substance abuse testing"[Text Word]) OR "drug abuse screening"[Text Word]) OR "drug abuse screening instruments"[Text Word]) OR "drug abuse screening test"[Text Word]) OR "drug abuse screening scale"[Text Word]) OR "drug abuse testing"[Text Word]))

((indigenous population OR Services, Indigenous Health OR american indians OR american indians/Alaska OR american indigenous populations OR american indigenous adolescents OR native American OR indigenous adolescents OR aboriginum OR aboriginal) AND (Alcoholism OR alcohol dependence OR consumption) AND (questionnaire OR screening instruments OR test)) 


\begin{tabular}{|c|c|c|}
\hline Cochrane & 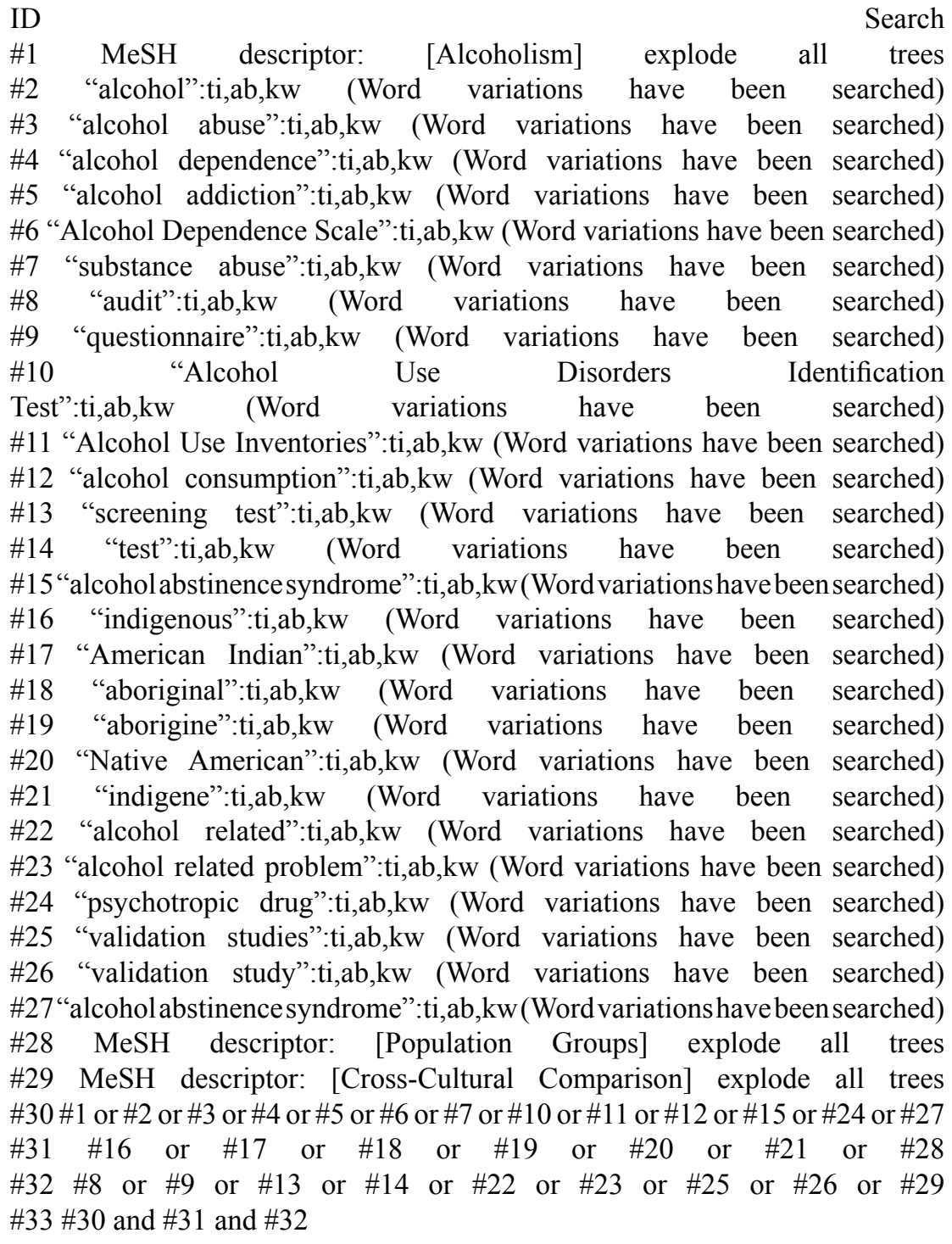 & 132 \\
\hline PSICOInfo & $\begin{array}{l}\text { Any Field: indigenous populations OR american indians OR Native americans } \\
\text { OR indigenous health services OR indigenous OR aboriginal OR aboriginal } \\
\text { populations }\end{array}$ & 254 \\
\hline
\end{tabular}

\section{Selection of Studies and Eligibility Criteria}

After the execution of the search strategies, the publications were gathered in a single basis for the exclusion of the duplicates, identified through the End Note ${ }^{\circledR}$ program. Two reviewers independently selected the studies in two phases:

1. 1. Reading titles and abstracts

2. Reading full text. Disagreements were resolved by a third reviewer (VA).

Only studies with a research design that addressed the evaluation of alcohol use in indigenous communities were included. There were no restrictions on the date of publication of the study and language.

\section{Data Collection}

The data collection was done in electronic form, specially designed for this purpose, containing the main characteristics of the inserted publications. The articles were evaluated according to their method and instrument used for alcohol evaluation, and included only studies that cited the use of instruments for evaluation. 


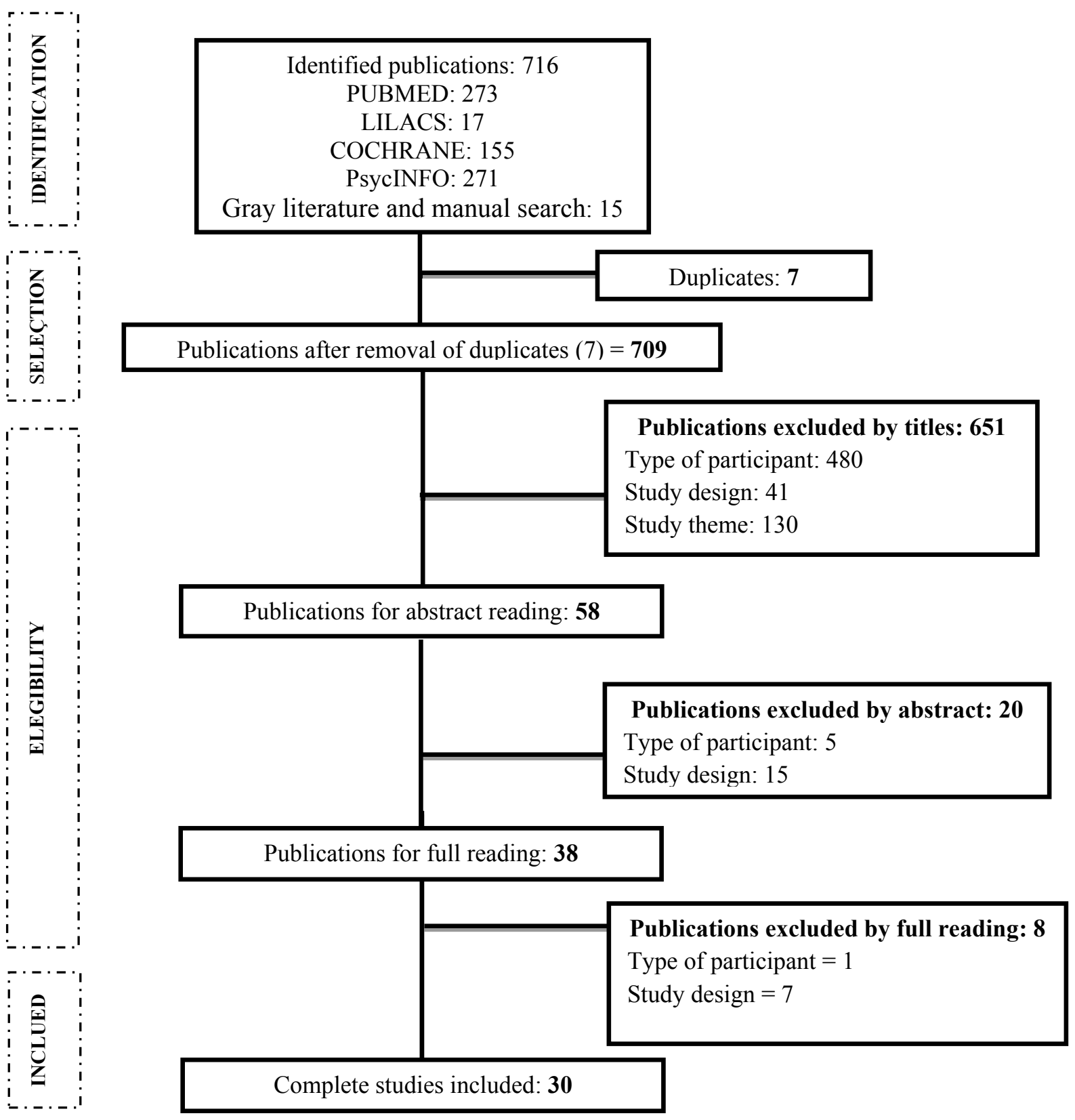

Figure 1. Selection's flowchart of studies for the systematic review.

\section{Results}

The review found a total of 675 publications that, following the stepwise evaluation, resulted in 30 studies included in the established eligibility criteria. The selection and exclusion processes are described in Figure I.

Most studies on alcohol use assessment included in the review were conducted in countries of the Americas (28); only one was conducted in Asia and one in Oceania, totaling thirty studies. Of these, twenty were developed in the USA, three in Canada, three in Brazil, two in
Venezuela, one in Australia and one in Taiwan. The publication date of the studies ranged from 1978 to 2013. Most studies (19) were published between 2000 and 2013. The main objectives of the studies were: to investigate, understand and analyze the prevalence of alcohol use; compare the use of alcohol between indigenous and non-indigenous; describe the prevalence, behaviors, and comorbidities associated with alcohol; investigate biological markers for alcohol consumption; and evaluate instruments, establish measures and validate instruments (Table 2). 
Table 2

Characteristics of the Studies Included in the Systematic Review

\begin{tabular}{|c|c|c|c|c|c|c|}
\hline Study & Local & Ethnicity & $\begin{array}{l}\text { Sample size } \\
\text { (indígenous) }\end{array}$ & Instruments & $\begin{array}{l}\text { Collection } \\
\text { method }\end{array}$ & $\begin{array}{c}\text { Cross- } \\
\text { cultural } \\
\text { validation }\end{array}$ \\
\hline
\end{tabular}

\begin{tabular}{|c|c|c|c|c|c|c|c|}
\hline $\begin{array}{l}\text { Khan, Robinson, } \\
\text { Smith, \& } \\
\text { Dillard, } 2013\end{array}$ & Alaska/USA & NE & 125 & Questionnaire & $\begin{array}{c}\text { Self- } \\
\text { applied }\end{array}$ & DR & $\begin{array}{l}\text { Transversal/ } \\
\text { Quantitative }\end{array}$ \\
\hline $\begin{array}{l}\text { Currie et al., } \\
2011\end{array}$ & Canada & NE & 60 & AUDIT & $\begin{array}{c}\text { Self- } \\
\text { applied }\end{array}$ & DR & $\begin{array}{c}\text { Longitudinal/ } \\
\text { Quantitative }\end{array}$ \\
\hline Kassab, 2011 & Brazil & Terena & 30 & Questionnaire & $\begin{array}{c}\text { Self- } \\
\text { applied }\end{array}$ & DR & $\begin{array}{l}\text { Transversal/ } \\
\text { Quantitative }\end{array}$ \\
\hline $\begin{array}{l}\text { Melo, Maciel, } \\
\text { Oliveira, \& } \\
\text { Silva, } 2011\end{array}$ & Brazil & Potiguara & 55 & $\begin{array}{c}\text { Semi-structured } \\
\text { interview }\end{array}$ & $\begin{array}{c}\text { Home } \\
\text { interview }\end{array}$ & DR & $\begin{array}{l}\text { Transversal/ } \\
\text { Qualitative }\end{array}$ \\
\hline $\begin{array}{l}\text { Seale et al., } \\
2010\end{array}$ & Venezuela & Arawak & 32 & $\begin{array}{c}\text { AUDIT; CAGE; } \\
\text { Questionnaire }\end{array}$ & $\begin{array}{c}\text { Home } \\
\text { interview }\end{array}$ & DR & $\begin{array}{c}\text { Transversal/ } \\
\text { Quali- } \\
\text { quantitate }\end{array}$ \\
\hline $\begin{array}{l}\text { MacMillan et } \\
\text { al., } 2008\end{array}$ & Canada & $\mathrm{NE}$ & 769 & OFNRHS & $\begin{array}{c}\text { Home } \\
\text { interview }\end{array}$ & DR & $\begin{array}{l}\text { Transversal/ } \\
\text { Quantitative }\end{array}$ \\
\hline $\begin{array}{l}\text { O’Malley et al., } \\
2008\end{array}$ & Alaska/USA & $\mathrm{NE}$ & 101 & Questionnaire & $\begin{array}{l}\text { Clinical } \\
\text { interview }\end{array}$ & DR & $\begin{array}{l}\text { Transversal/ } \\
\text { Quantitative }\end{array}$ \\
\hline Yen et al., 2008 & Taiwan & $\begin{array}{l}\text { Bunun, } \\
\text { Rukai, e } \\
\text { Paiwan }\end{array}$ & 401 & $\begin{array}{l}\text { AUDIT; } \\
\text { HAIS }\end{array}$ & $\begin{array}{l}\text { Clinical } \\
\text { interview }\end{array}$ & DR & $\begin{array}{l}\text { Transversal/ } \\
\text { Quantitative }\end{array}$ \\
\hline $\begin{array}{l}\text { Tann, Yabiku, } \\
\text { Okamoto, \& } \\
\text { Yanow, } 2007\end{array}$ & USA & $\mathrm{NE}$ & - & BRFSS & $\begin{array}{l}\text { Telephone } \\
\text { interview }\end{array}$ & DR & $\begin{array}{l}\text { Transversal/ } \\
\text { Quantitative }\end{array}$ \\
\hline $\begin{array}{l}\text { Schlesinger, } \\
\text { Ober, McCarthy, } \\
\text { Watson, \& } \\
\text { Seinen, } 2007\end{array}$ & Alaska/USA & $\mathrm{NE}$ & 175 & IRIS & $\begin{array}{l}\text { Computer } \\
\text { interview }\end{array}$ & DR & $\begin{array}{l}\text { Transversal/ } \\
\text { Quantitative }\end{array}$ \\
\hline $\begin{array}{l}\text { Souza, } \\
\text { Schweickardt, \& } \\
\text { Garnelo, } 2006\end{array}$ & Brazil & Tukano & 28 & CAGE & $\begin{array}{l}\text { Home } \\
\text { interview }\end{array}$ & VA & $\begin{array}{l}\text { Transversal/ } \\
\text { Qualitative }\end{array}$ \\
\hline $\begin{array}{l}\text { O'Connell et al., } \\
2006\end{array}$ & USA & $\mathrm{NE}$ & 1287 & AI-SUPERPFP & $\begin{array}{l}\text { Computer } \\
\text { interview }\end{array}$ & DR & $\begin{array}{l}\text { Transversal/ } \\
\text { Quantitative }\end{array}$ \\
\hline $\begin{array}{l}\text { Wardman \& } \\
\text { Quantz, } 2005\end{array}$ & Canada & NE & 15 & $\begin{array}{l}\text { Semi-structured } \\
\text { interview }\end{array}$ & $\begin{array}{c}\text { Home } \\
\text { interview }\end{array}$ & DR & $\begin{array}{l}\text { Transversal/ } \\
\text { Qualitative }\end{array}$ \\
\hline $\begin{array}{l}\text { Shore \& Spicer, } \\
2004\end{array}$ & Australia & $\mathrm{NE}$ & 39 & Questionnaire & $\begin{array}{l}\text { Home } \\
\text { interview }\end{array}$ & DR & $\begin{array}{l}\text { Transversal/ } \\
\text { Qualitative }\end{array}$ \\
\hline $\begin{array}{l}\text { Duran et al., } \\
2004\end{array}$ & USA & $\mathrm{NE}$ & 234 & CIDI & $\begin{array}{l}\text { Clinical } \\
\text { interview }\end{array}$ & DR & $\begin{array}{l}\text { Transversal/ } \\
\text { Quantitative }\end{array}$ \\
\hline $\begin{array}{l}\text { Seale, Seale, } \\
\text { Alvarado, } \\
\text { Vogel, \& Terry, } \\
2002\end{array}$ & Venezuela & $\mathrm{NE}$ & 211 & AUDIT & $\begin{array}{l}\text { Home } \\
\text { interview }\end{array}$ & DR & $\begin{array}{l}\text { Transversal/ } \\
\text { Quantitative }\end{array}$ \\
\hline
\end{tabular}


Shore, Manson,

2002

Alaska/USA NE $\quad 754$

Screening Clinical

questionnaire interview

DR

Transversal/

USA

NE

275

CAGE-T

Clinical

interview

PE

Transversal/

2001

Baldwin,

Maxwell,

Fenaughty,

Alaska/USA NE

147

RBA

Home

interview

DR

Transversal/

Trotter, \&

Stevens, 2000

Bull, Kvigne,

Leonardson,

Lacina, \& Welty,

USA

NE

208

SAQ $\begin{array}{r}\text { Clinical } \\ \text { interview }\end{array}$

VA

Transversal/

1999

Giuliano,

Papenfuss,

Zapien, Tilousi,

USA Hopi

559

Questionnaire

Home

interview

DR

Transversal/

\& Nuvayestewa,

1998

Ehlers, Garcia-

Andrade,

Wall, Sobel, \&

USA NE

47

Screening

questionnaire

Clinical

interview

DR

Transversal/

Phillips, 1998

Robin, Long,

Rasmussen,

Albaugh, \&

Goldman,1998

$$
\text { USA }
$$

NE

582

SMAST

Clinical

interview

DR

Transversal/

Quantitative

Garcia-Andrade,

Wall, \& Ehlers,

1997

USA

NE

40

Rating Scale

Self-

Auto Subjective

applied

DR

Transversal/

Quali-

quantitative

Lowe, Long,

Wallace, \&

USA NE

SMAST;

Clinical

Transversal/

Questionnaire

interview

DR

Quantitative

McMahon et al., 1993

Alaska/USA NE 85

ADS

Clinical

interview

Transversal/

May \& Smith,

1988

USA Navajo

174

Questionnaire

Self-

applied

DR

Transversal/

Hughes \&

Dodder, 1984

USA Prairie

58

Questionnaire

Self-

applied

DR

Transversal/

Weisner,

Wiebel-Orlando,

USA

NE

155

Self-reporting

Clinical

interview

DR

Transversal/

\& Long, 1984

Forslundl, 1978

USA

Shoshone

e Arapahoe

120

Questionnaire

Self-
applied

DR

Transversal/

Quantitative

Note. DR= Do not report; PE= Precision; VA= Validity; AUDIT: Alcohol Use Disorders Identification Test; SAQ: Questionnaires self-applied; HAIS: Hanil Alcohol Insight Scale; ADS: Dependence of Alcohol Scale; IRIS: Indigenous Risk Impact Screen; OFNRHS: Regional Health Survey of the First Nations of Ontario; RBA: Risk Behavior Assessment; BRFSS: Behavioral Risk Factor Surveillance System: SMAST: Michigan Alcoholism Screening; AI-SUPERPFP: Utilization American Service Indian, Psychiatric Epidemiology, Risk and Protection Project Factors; CIDI: Composite International Diagnostic Interview. 
The 30 included studies involved a sample of 7,189 participants. Most studies (27) presented only the evaluation of Indians, others (Hughes \& Dodder, 1984; MacMillan et al., 2008; O'Connell et al., 2006) included other populations. For this review, only the indigenous participants were considered. In nine studies the ethnic groups were described, being Arawak, Bunun, Rukai, Paiwan, Hopi, Navajo, Potiguara, Prairie, Shoshone, Arapahoe, Terena and Tukano. The remaining 21 studies did not specify the ethnicity of the populations studied, citing the issue of secrecy and ethics as a means of protecting the community from exposure. As for the adaptation of instruments for application in indigenous populations, only three had this objective, with two validity studies (Bull et al., 1999; Souza et al., 2006) and a precision study (Saremi et al., 2001); the others did not describe any adaptation procedure to the culture.

Twenty different instruments were used to assess alcohol use in the studies (Table 3). Some of them were created for the purpose of the research, others were already recommended by the WHO and others were adapted for the indigenous context. Their names were preserved as cited in the articles aiming at the fidelity of the authors' initial proposal.

Table 3

Instruments Used in the Studies Included in the Systematic Review

\begin{tabular}{|c|c|}
\hline Instruments & Studies \\
\hline Questionnaire & $\begin{array}{l}\text { Forslundl, 1978; Giuliano et al., 1998; Hughes \& Dodder, 1984; Kassab, 2011; } \\
\text { Khan et al., 2013; Lowe et al., 1997; May \& Smith, 1988; O’Malley et al., 2008; } \\
\text { Seale et al., 2010; Shore \& Spicer, } 2004\end{array}$ \\
\hline AUDIT & Currie et al., 2011; Seale et al., 2002; Seale et al., 2010; Yen et al., 2008 \\
\hline Semi-structured interview & Melo et al., 2011; Wardman \& Quantz, 2005 \\
\hline Screening questionnaire & Ehlers et al., 1998; Shore et al., 2002 \\
\hline CAGE & Seale et al., 2010; Souza et al., 2006 \\
\hline $\mathrm{CAGE}-\mathrm{T}$ & Saremi et al., 2001 \\
\hline SAQ & Bull et al., 1999 \\
\hline HAIS & Yen et al., 2008 \\
\hline Self-reporting scale & Weisner et al., 1984 \\
\hline Rating Scale Auto Subjective & Garcia-Andrade et al., 1997 \\
\hline ADS & McMahon et al., 1993 \\
\hline IRIS & Schlesinger et al., 2007 \\
\hline OFNRHS & MacMillan et al., 2008 \\
\hline RBA & Baldwin et al., 2000 \\
\hline BRFSS & Tann et al., 2007 \\
\hline SMAST & Lowe et al., 1997; Robin et al., 1998 \\
\hline AI-SUPERPFP & O’Connell et al., 2006 \\
\hline CIDI & Duran et al., 2004 \\
\hline
\end{tabular}

Note. AUDIT: Alcohol Use Disorders Identification Test; SAQ: Questionnaires self-applied; HAIS: Hanil Alcohol Insight Scale; ADS: Dependence of Alcohol Scale; IRIS: Indigenous Risk Impact Screen; OFNRHS: Regional Health Survey of the First Nations of Ontario ; RBA: Risk Behavior Assessment; BRFSS: Behavioral Risk Factor Surveillance System: SMAST: Michigan Alcoholism Screening; AI-SUPERPFP: Utilization American Service Indian, Psychiatric Epidemiology, Risk and Protection Project Factors; CIDI: Composite International Diagnostic Interview. 
The questionnaires refer to instruments constructed and adapted according to the particularities of the populations, interests and objectives of the studies. In addition, we have identified 10 studies (Forslundl, 1978; Giuliano et al., 1998; Hughes \& Dodder, 1984; Kassab, 2011; Khan et al., 2013; Lowe et al., 1997; May \& Smith, 1988; O’Malley et al., 2008; Seale et al., 2010; Shore $\&$ Spicer, 2004) that used questionnaires to describe the tool used to assess alcohol use in indigenous populations. These present a pattern in their characteristics, with closed questions about the habits of consumption of alcoholic beverages, frequency, quantity, type and damages. Some have presented specific questions, such as the consequences of the use, associated or not with violence (Kassab, 2011), the evaluation of last consumption in the last six months per quarter, and the perception of pregnant women on alcohol (Khan et al., 2013), the reasons for drinking (Forslundl, 1978), the history of drinking (Lowe, et al., 1997) and beliefs about the effects of drinking and social control over the use of drink in the community (Shore \& Spicer, 2004). The evaluation criteria of Diagnostic and Statistical Manual of Mental Disorders IV (DSM-IV) and International Classification of Diseases 10th version (ICD-10), as well as the CAGE questionnaire and Alcohol Use Disorders Identification Test (AUDIT) evaluation model, were guiding resources for some instruments (O'Malley et al., 2008; Seale et al., 2010; Shore \& Spicer, 2004).

The Alcohol Use Disorder Identification Test (AUDIT) is one of the instruments recommended by the (WHO) for tracking alcohol consumption (Babor, Higgins-Biddle, Saunders, Monteiro, \& World Health Organization, 2001). Composed of ten questions that examine the amount and frequency of alcohol consumption, as well as its behaviors and consequences, its goal is to identify alcohol use disorders. This instrument was used by four studies (Currie et al., 2011; Seale et al., 2002; Seale et al., 2010; Yen et al., 2008). Seale et al. (2002) added, together with the AUDIT, a question to identify the first contact with the alcoholic beverage and the type of drink consumed by the indigenous.

Two studies (Melo et al., 2011; Wardman \& Quantz, 2005) used semi-structured interviews as a strategy for data collection. These studies developed a self-paced questionnaire that asked questions about the characteristics of episodes and perceptions of excessive alcohol consumption, the risks and protective factors for compulsive vices, quantity and frequency of consumption, types of drinks, sociodemographic issues and cultural activities. The Screening Questionnaires are short instruments, with a maximum of three items, used in a university context and in health unit receptions. They were applied to evaluate the alcohol use and abuse of individuals in two studies (Ehlers et al., 1998; Shore et al., 2002). The CAGE consists of four issues concerning the anagram Cut-down, Annoyed, Guilty and Eye-opener. The application consists of an interview, in which the following aspects are investigated: "Have you ever felt that you should reduce the amount of alcohol or stop drinking?" (Cut down); "Do people annoy you because they criticize your way of drinking?" (Annoyed); "Do you feel annoyed with yourself by the way you usually drink alcohol?" (Guilty); "Do you usually drink alcohol in the morning to reduce nervousness or hangover?" (Eye-opener). The results of Table 3 showed that two studies used CAGE (Seale et al., 2010; Souza et al., 2006). One variation of this instrument is the CAGE-T, which added a question about alcohol treatment in life ("Have you ever been treated for alcoholism?"). The CAGE-T was used in the research developed by Saremi et al. (2001). The other instruments of data collection were cited in only one or two studies. The first one, Self Administered Questionnaire (SAQ), used by Bull et al. (1999), is a series of questions used to identify the risk of drinking among prenatal patients. It has questions about quantity, frequency of alcohol use, including assessment of the behavior of binge drinking, which refers to drinking a lot in a short period of time. Yen et al. (2008) worked with the Hanil Alcohol Insight Scale (HAIS) instrument, which contains twenty items that measure the acceptance or denial of alcoholism subjects, composed of sentences about the positive view and negative view about their behavior towards alcohol. A Self Reporting Scale is an instrument that classifies participants as abstainers, moderate drinkers and 
heavy drinkers, according to their frequency and quantity of ingested drinks, used by Weisner et al. (1984). The Rating Scale Auto Subjective, adopted in the study by Garcia-Andrade et al. (1997), is composed of thirteen items that evaluate the feelings about the behavior of alcohol intoxication and expectations when drinking. Already Mcmahon et al. (1993) used the Alcohol Dependence Scale (ADS), which evaluates participants' daily and weekly alcohol intake. Thus, when subjects respond affirmatively about alcohol use, they are also evaluated for alcohol dependence behaviors. Utilized in a survey in Canada by Schlesinger et al. (2007), the Ontario First Nations Regional Health Survey (OFNRHS) has a subscale that evaluates alcohol consumption in the last twelve months. Baldwin et al. (2000) applied the Risk Behavior Assessment (RBA), which investigates the frequency, amount, and patterns of alcohol use in the last 30 days and throughout life. Tann et al. (2007) worked with the Risk Factor Surveillance System Behavior (BRFSS), which measures risk factors for binge drinking. The Short Michigan Alcohol Screening Test (SMAST) identifies the evidence of alcoholism and problems related to alcohol use, which was used in the studies by Lowe et al. (1997) and Robin et al. (1998). O'Connell et al. (2006) worked with the American Indian Service Utilization Psychiatric Epidemiology Risk and Protective Factors Project (AI-SUPERPFP), which included measures of assessment not only of patterns of alcohol use, but also of the identification of psychiatric disorders and quality of life. Finally, Duran et al. (2004) applied an instrument called the Composite International Diagnostic Interview (CIDI), which has an interview script format based on the DSM-IV and the ICD-10, which evaluated dependence and heavy drinking. All of the above-mentioned instruments were used in the studies with the objective of evaluating alcohol use in indigenous populations, some studies focused on evaluation as the main objective. Those who did not present the evaluation as the main objective used the instruments for sample selection of subjects with problems with alcohol use.

The alcohol use assessment instruments were applied in the studies in four different ways. The method of application of the instruments through clinical interview was used in eleven studies (Bull et al., 1999; Duran et al., 2004; Ehlers et al., 1998; Lowe et al., 1997; Mcmahon et al., 1993; Shore et al., 2002; Weisner et al., 1984; Yen et al., 2008). The clinical interviews were in the primary health care units or in the emergency care units, conducted by health professionals or researchers, often taking advantage of space and work routine. In order to evaluate the effectiveness of the study, the results obtained in this study are presented in Table 2. In previous studies, (Shore \& Spicer, 2004; Souza et al., 2006; Wardman \& Quantz, 2005) the professionals went to the homes of the natives, accompanied by the leaders and health agents, to assist them during the interviews. The interviews were conducted by researchers, health professionals and indigenous people working in areas of healthcare with research training. In seven studies, the instruments were self-administered (Currie et al., 2011; Forslundl, 1978; GarciaAndrade et al., 1997; Hughes \& Dodder, 1984; Kassab, 2011; Khan et al., 2013; May \& Smith, 1988) with the forms delivered to the individuals who completed them. The studies were applied by the researchers in a school context, in health groups or individually. Besides, three studies (O'Connell et al., 2006; Schlesinger et al., 2007; Tann et al., 2007) used media interview as tool to realize the alcohol evaluation in indigenous, by using computer and tablet.

\section{Discussion}

This systematic review compiled the tools used to assess alcohol use in indigenous communities. As stated, the set of publications revealed the plurality of instruments used that showed the possibility of measuring alcohol consumption in ethnic minorities. The presence of several evaluation instruments, ranging from those used in non-indigenous populations to instruments created with a focus on indigenous populations, reinforces WHO's recommendation to establish care for evaluation instruments. These studies have shown, therefore, the care with cultural differences, language and the adaptation of the instruments to each population, 
when necessary (Organização Pan-Americana da Saúde [OPAS]/ Organização Mundial da Saúde [OMS], 2001).

This study sought to identify the largest number of published studies, in order to advance the knowledge of the evaluation instruments and their particularities, as well as to examine the possibilities of measures employed in the different contexts. It should be noted that the systematization of the data in this review may not have included all the particularities of the instruments, since the reviewers do not pretend to make a universal generalization of knowledge, but rather focused on a critical reflection of the studied phenomenon.

Research on the evaluation of alcohol use has a history that should be considered, since, as demonstrated in the three older studies found in this review (Forslundl, 1978; Hughes \& Dodder, 1984; May \& Smith, 1988), the phenomenon does not only exist in the present, and its importance has been recognized in publications since 1978. Most of the studies included in this review are concentrated from the year 2000, which shows a late interest by the researchers. These chronological data on the evaluation of alcohol use in traditional people reinforce the need for further research in the area to confront and understand this serious public health problem.

Two studies have attempted to validate the adopted instrument (Bull et al., 1999; Souza et al., 2006) and one to evaluate its accuracy (Saremi et al., 2001). Validity evidences the accumulation of studies that prove the legitimacy of the conceptual inferences made for the obtained scores, and accuracy is considered the reliability of the data obtained by the instrument, which can be verified, for example, by the constancy of the results of a subject at different times of application or with similar test applications (Anastasi \& Urbina, 2000). As previously mentioned, CAGE was considered inappropriate by one study (Souza et al., 2006) and accurate in another, presenting sensitivity for the identification of dependent behaviors (Saremi et al., 2001). The validity of the SAQ instrument was evaluated through its results compared to analyses of an extensive interview and data collected in the medical records. It was revealed that the instrument is sen- sitive for the detection of pregnant women who consumed alcohol during pregnancy (Bull et al., 1999). The lack of validation studies makes it difficult to verify the quality of the instruments, since only then will we have a useful and reliable screening and diagnosis tool for the evaluation of alcohol use in this population.

In the studies presented, the most used instrument model was the questionnaire, elaborated according to each research proposal, adopting in each study a different format and pattern. Some of these included, in addition to the assessment of alcohol, cultural, socioeconomic and health data in general (MacMillan et al., 2008; O'Connell et al., 2006; Tann et al., 2007). The questionnaires, composed of open or closed questions, allowed the researchers an individual construction that sought to approach the variables studied and the differences found in the field of study. Standardized instruments, such as AUDIT and CAGE, did not undergo changes in their structures, except for one study (Souza \& Garnelo, 2006), which pointed out the need to substitute the term guilt for shame, since, according to the author, the term guilt is not understood in the indigenous universe, and shame is a term more familiar to the population.

The instruments used as the main form of measurement were the evaluation of frequency, type and mode of drinking. The gender assessment did not differ in terms of the instruments, but in the quantity for the calculation of the drink, and the measure of drinking for the women was lower, based on the resistance against consumption and the data of the studies that indicate that they are more vulnerable to the effects of "heavy" alcohol use (Saremi et al., 2001). According to Edwards et al. (2005), after an equivalent dose of drink, the greater amount of fat in women leads to a higher concentration of alcohol in the blood, which increases the potential for intoxication; therefore, the need for measurement standards differentiated by the results achieved, it is necessary to carry out more research in Brazil, in particular, including a larger number of ethnicities, so that we can advance in the studies of alcohol use in indigenous populations and in the validation of the instruments used. Thus, allowing possibilities for intervention after the 
evaluation, in order to address this serious public health problem in indigenous reserves, which is the problematic use of alcohol. To group thirty studies with their particularities by ethnicities and their different ways of evaluating the use of beverages is a great advance, in the sense of making new studies possible and new ways of thinking about the measurement in the national scenario, since the evaluation by standardized instruments is widespread in indigenous populations outside Brazil. Thus, it is feasible to create intervention and evaluation programs, by health professionals, of alcohol use, combined with the instruments as a work tool. This systematic review expanded the knowledge of new instruments and new forms of measurement in ethnic minorities. In addition, a clearer definition of the possibility of evaluations in different contexts was obtained, provided that the differences and limitations of the populations studied were observed. Based on this, it is necessary to develop more research on the subject in question, given the importance of the theme and the low national production. Among the possible research approaches could be the development of new instruments, the validity and construction of guidance manuals for health professionals, the standardization of measures for ethnic contexts and the creation of interventions based on the results of compatible instruments with the traditional contexts. Indigenous healthcare needs instruments to support the work of professionals and to ensure that indigenous people are given adequate referrals for interventions focused on treatment and prevention. This serious problem needs to be addressed using a multidisciplinary approach and through national surveys, since it is still little explored in public health, even in the face of so many negative consequences experienced by communities and health professionals.

\section{References}

Anastasi, A., \& Urbina, S. (2000). Testagem Psicológica. Porto Alegre, RS: Artes Médicas.

Babor, T. F., Higgins-Biddle, J. C., Saunders, J. B., Monteiro, M. G., \& World Health Organization, Dept. of Mental Health and Substance Dependence. (2001)|' AUDIT: The alcohol use disor- ders identification test ( $2^{\text {nd }}$ Ed.). Geneva: World Health Organization.

Baldwin, J. A., Maxwell, J. C. C., Fenaughty, A. M., Trotter, R. T., \& Stevens, S. J. (2000). Alcohol as a risk factor for HIV transmission among American Indian and Alaska Native drug users. American Indian and Alaska Native Mental Health Research, 9(1), 1-16.

Bull, L. B. H., Kvigne, V. L., Leonardson, G. R., Lacina, L., \& Welty, T. K. (1999). Validation of a self-administered questionnaire to screen for prenatal alcohol use in Northern Plains Indian women. American Journal of Preventive Medicine, 16(3), 240-243. doi: 10.1016/S07493797(98)00158-5

Clarke, M., \& Oxman, A. D. (2000). Cochrane Reviewers' Handbook 4.1. In Review Manager (RevMan) [Computer program]. Version 4.1. Oxford, England: The Cochrane Collaboration.

Currie, C. L., Wild, T. C., Schopflocher, D. P., Laing, L., Veugelers, P. J., Parlee, B., \& McKennitt, D. W. (2011). Enculturation and Alcohol Use Problems among Aboriginal University Students. The Canadian Journal of Psychiatry, 56(12), 735-742.

Duran, B., Sanders, M., Skipper, B., Waitzkin, H., Malcoe, L. H., Paine, S., \& Yager, J. (2004). Prevalence and Correlates of Mental Disorders among Native American Women in Primary Care. Journal of Public Health, 94(1), 71-77. doi: 10.2105/AJPH.94.1.71

Edwards, G., Marshall, E. J., \& Cook, C. C. H. (2005). O tratamento do alcoolismo: Um guia para profissionais da saúde (4. ed.). Porto Alegre, RS: Artmed.

Ehlers, C. L., Garcia-Andrade, C., Wall, T. L., Sobel, D. F., \& Phillips, E. (1998). Determinants of P3 amplitude and response to alcohol in Native American Mission Indians. Neuropsychopharmacology, 18(4), 282-292. doi: 10.1016/S0893133X(97)00160-7

Forslundl, M. A. (1978). Functions of drinking for Native American and White youth. Journal of Youth and Adoleseence, 7(3), 327-332. doi: 10.1007/BF01537983

Garcia-Andrade, C., Wall, T. L., \& Ehlers, C. L. (1997). The firewater myth and response to alcohol in Mission Indians. American Journal of Psychiatry, 154(7), 983-938. doi: 10.1176/ ajp.154.7.983 
Giuliano, A., Papenfuss, M., Zapien, J. G., Tilousi, S., \& Nuvayestewa, L. (1998). Prevalence of chronic disease risk and protective behaviors among American Indian women living on the Hopi reservation. American Indian Women's Health, 8(3), 160-167. doi: 10.1016/S10472797(97)00200-7

Hughes, S. P., \& Dodder, R. A. (1984). Alcohol consumption patterns among American Indian and White college students. Journal of Studies on Alcohol, 45(5), 433-439. doi: 10.15288/ jsa.1984.45.433

Kassab, M. S. (2011). Identificar o consumo de álcool entre adolescentes indígenas da etnia Terena nas aldeias do município de Sidrolandia (Monography, Universidade Federal de Mato Grosso do Sul/ Fundação Oswaldo Cruz- Unidade Cerrado Pantanal, Curso de Pós-Graduação em Atenção Básica em Saúde da Família. Sidrolândia, MS, Brazil).

Khan, B. A., Robinson, R. F., Smith, J. J., \& Dillard, D. A. (2013). Prenatal alcohol exposure among Alaska Native/American Indian infants. International Journal of Circumpolar Health, 72. doi: 10.3402/ijch.v72i0.20973

Langdon, E. J. (2001). O que beber, como beber e quando beber: $\mathrm{O}$ contexto sociocultural no alcoolismo entre as populações indígenas. In Seminário sobre Alcoolismo e DST/AIDS entre os Povos Indígenas (pp. 83-97). Brasília, DF: Ministério da Saúde.

Langdon, E. J. M. (2013). O abuso de álcool entre os povos indígenas no Brasil: Uma avaliação comparativa. In M. L. P. Souza, Processos de alcoolização indígena no Brasil: Perspectivas plurais (pp. 27-46). Rio de Janeiro, RJ: Editora da Fundação Oswaldo Cruz.

Liberati, A., Altman, D. G., Tetzlaff, J., Mulrow, C., Gøtzsche, P. C., Ioannidis, J. P., \& Moher, D. (2009). The PRISMA statement for reporting systematic reviews and meta-analyses of studies that evaluate health care interventions: Explanation and elaboration. Annals of Internal Medicine, 151(4), W-65.

Lowe, L., Long, C. R., Wallace, R. B., \& Welty, T. K. (1997). Epidemiology of alcohol use in a group of older American Indians. Annals of Epidemiology, 7(4), 241-248. doi: 10.1016/S10472797(97)00003-3

MacMillan, H. L., Jamieson, E., Walsh, C. A., Wong, M. Y., Faries, E. J., McCue, H., MacMillan, A.
B., \& Offord, D. R. (2008). First Nations women's mental health: Results from an Ontario survey. Archives of Women's Mental Health, 11(2), 109-115. doi: 10.1007/s00737-008-0004-y

May, P. A., \& Smith, M. B. (1988). Some Navajo Indian opinions about alcohol abuse and prohibition: A survey and recommendations for policy. Journal of Studies on Alcohol, 49(4), 324-334. doi: 10.15288/jsa.1988.49.324

McMahon, B. J., Parkinson, A. J., Bulkow, L., Davidson, M., Wainright, K., Wolfe, P., \& Schiffman, P. G. S. (1993). Immunogenicity of the 23-valent pneumococcal polysaccharide vaccine in Alaska Native chronic alcoholics compared with nonalcoholic Native and non-Native controls. American Journal of Medicine, 95(6), 589-594. doi: 10.1016/0002-9343(93)90354-R

Melo, J. R. F., Maciel, S. C., Oliveira, R. C. C., \& Silva, A. O. (2011). Implicações do uso do álcool na comunidade indígena Potiguara. Physis Revista de Saúde Coletiva, 21(1), 319-333. doi: 10.1590/S0103-73312011000100019

National Health Foundation. (2002). Politica Nacional de Atenção à Saúde dos Povos Indígenas. Brasília, DF: Ministério da Saúde.

O’Connell, J., Novins, D. K., Beals, J., Croy, C., Barón, A. E., Spicer, P., Buchwald, D., \& the American Indian Service Utilization, Psychiatric Epidemiology, Risk and Protective Factors Project Team. (2006). The relationship between patterns of alcohol use and mental and physical health disorders in two American Indian populations. Addiction, 101(1), 69-83. doi: 10.1111/j.1360-0443.2005.01308.x

Oliveira, M. (2001). Alcoolismo entre os Kaingang: Do sagrado e lúdico à dependência. In Ministério da Saúde, Anais do Seminário sobre Alcoolismo e DST/AIDS entre os Povos Indigenas (pp. 99-125). Brasília, DF: Ministério da Saúde.

O’Malley, S. S., Robin, R. W., Levenson, A. L., GreyWolf, I., Chance, L. E., Hodgkinson, C. A., ...Goldman, D. (2008). Naltrexone alone and with sertraline for the treatment of alcohol dependence in Alaska natives and non-natives residing in rural settings: A randomized controlled trial. Alcoholism: Clinical and Experimental Research, 32(7), 1271-1283. doi: 10.1111/j.15300277.2008.00682.x

Organização Pan-Americana da Saúde / Organização Mundial da Saúde. (2001). Relatório sobre a Saúde no Mundo. São Paulo, SP: Gráfica Brasil. 
Pasquali, L. (Ed.). (2010) Instrumentação psicológica: Fundamentos e práticas. Porto Alegre, RS: Artmed.

Robin, R. W., Long, J. C., Rasmussen, J. K., Albaugh, B., \& Goldman, D. (1998). Relationship of binge drinking to alcohol dependence, other psychiatric disorders, and behavioral problems in an American Indian tribe. Alcoholism: Clinical and Experimental Research, 22(2), 518-523. doi: 10.1111/j.1530-0277.1998.tb03682.x

Saremi, A., Hanson, R. L., Williams, D. E., Roumain, J., Robin, R. W., Long, J. C., Goldman, D., \& Knowler, W. C. (2001). Validity of the CAGE questionnaire in an American Indian population. Journal of Studies on Alcohol and Drugs, 62(3), 294-300. doi: 10.15288/jsa.2001.62.294

Schlesinger, C. M., Ober, C., McCarthy, M. M., Watson, J. D., \& Seinen, A. (2007). The development and validation of the Indigenous Risk Impact Screen (IRIS): A 13-item screening instrument for alcohol and drug and mental health risk. Drug and Alcohol Review, 26(2), 109-117. doi: 10.1080/09595230601146611

Seale, J. P., Seale, J. D., Alvarado, M., Vogel, R. L., $\&$ Terry, N. E. (2002). Prevalence of problem drinking in a Venezuelan Native American population. Alcohol and Alcholism, 37(2), 198-204. doi: 10.1093/alcalc/37.2.198

Seale, J. P., Shellenberger, S., Sanchez, N., Vogel, R. L., Villalobos, E., Girton, F.S., Seale, D. M., \& Okosun, I. S. (2010). Characteristics of problem drinking in an urban South American indigenous population. Substance Use \& Misuse, 45(13), 2185-2202. doi: 10.3109/10826081003682891

Shore, J. H., Manson, S. M., \& Buchwald, D. (2002) Screening for alcohol abuse among urban Native Americans in a primary care setting. Psychiatric Services, 53(6), 757-760. doi: 10.1176/appi. ps.53.6.757

Shore, J. H., \& Spicer, P. (2004). A model for alcohol-mediated violence in an Australian Aboriginal community. Social Science \& Medicine, 58(12), 2509-2521. doi: 10.1016/j. socscimed.2003.09.022
Souza, M. L. P., \& Garnelo, L. (2006). Desconstruindo o alcoolismo: Notas a partir da construção do objeto de pesquisa no contexto da saúde indígena. Revista Latinoamericana de Psicopatologia Fundamental, 9(2), 279-292.

Souza, M. L. P., Schweickardt, C., \& Garnelo, L. (2006). O processo de alcoolização em populações indígenas do Alto Rio Negro e as limitações do CAGE como instrumento de screening para dependência ao álcool. Revista Psiquiatria Clínica, 34(2), 90-96. doi: 10.1590/S010160832007000200005

Tann, S. S., Yabiku, S. T., Okamoto, S. K., \& Yanow, J. (2007). TRIADD: The risk for alcohol abuse, depression, and diabetes multimorbidity in the American Indian and Alaska native population. American Indian and Alaska Native Mental Health Research, 14(1), 1-23. doi: 10.5820/ aian.1401.2007.5

Wardman, D., \& Quantz, D. (2005). An Exploratory Study of Binge Drinking in the Aboriginal Population. American Indian and Alaska Native Mental Health Research, 12(1), 49-61. doi: 10.5820/ aian.1201.2005.49

Weisner, T. S., Wiebel-Orlando, J. C., \& Long, J. (1984). "Serious drinking" "White man's drinkings" and "teetotaling": Drinking levels and style in an urban American Indian population. Journal of studies on Alcohol, 45(3), 237-250. doi: 10.15288/jsa.1984.45.237

World Health Organization. (2004). Global Status Report on Alcohol and Health. Geneva: Author.

Yen, C., Hsiao, R. C., Ries, R., Liu, S., Huang, C., Chang, Y., \& Yu, M. (2008). Insight into alcohol-related problems and its associations with severity of alcohol consumption, mental health status, race, and level of acculturation in southern Taiwanese indigenous people with alcoholism. The American Journal of Drug and Alcohol Abuse, 34(5), 553-556. doi: $10.1080 / 00952990802295220$

Received: 05/04/2017

$1^{\text {st }}$ revision: $31 / 08 / 2017$ Accepted: 06/09/2017

(c) BY The Author(s), 2018. Open Access. This article is distributed under the terms of the Creative Commons Attribution 4.0 International License (http://creativecommons.org/licenses/by/4.0/), which permits unrestricted use, distribution, and reproduction in any medium, provided you give appropriate credit to the original author(s) and the source, provide a link to the Creative Commons license, and indicate if changes were made. 